\title{
EFFECT OF ORGANIC MEDIA ON GROWTH AND DEVELOPMENT OF PATIOLA F1 HORNED VIOLET (Viola cornuta L.)
}

\author{
Dorota Janicka, Agnieszka Dobrowolska \\ Department of Horticulture, Laboratory of Ornamental Plants, West Pomeranian University of Technology in Szczecin \\ Papieża Pawła VI 3, 71-459 Szczecin, Poland \\ e-mail: Agnieszka.Dobrowolska@zut.edu.pl
}

Received: 10.04 .2012

\begin{abstract}
The specificity of horticultural production makes it possible to use substrates based on compost from municipal and industrial waste, particularly in the cultivation of ornamental plants. Experiments were conducted in the years 2005-2007. Six horned violet cultivars (Viola cornuta L.) from Patiola F1 group and four substrates were used in them: I - sphagnum peat; II - substrate from peat and compost $1(1: 1 \mathrm{v} / \mathrm{v})$; III - substrate from peat and compost $2(1: 1 \mathrm{v} / \mathrm{v}) ; \mathrm{IV}$ - coconut fibre. Compost 1 was prepared using municipal sewage sludge (35\%), potato pulp (35\%) and straw (30\%). Compost 2 was prepared using municipal sewage sludge $(35 \%)$, potato pulp (35\%) and sawdust (30\%). Composts after 10 months of composting were used in the research. The addition of municipal sewage sludge composts did not cause observable adverse changes in plants grown. Composts made from municipal sewage sludge are rich in nutrients. Plants that are grown in substrates with the addition of composts and in a peat substrate grow and develop properly without the necessity of introducing top dressing.
\end{abstract}

Key words: Viola cornuta, media, sewage sludge compost, chemical composition, morphological traits, greenness index

\section{INTRODUCTION}

For years, pansies and later horned violet have been among the most popular bedding and pot plants that are eagerly bought ( $\mathrm{S} \mathrm{tarte} \mathrm{k}$ et. al. 2006; Z a wadzińska and Janicka, 2007). Apart from fertilisation, an appropriate substrate has a significant influence on proper growth and development of these plants (S tarte k et. al. 2004 a, b; S tarte k et. al. 2006). In horticultural production, substrates of natural origin are introduced more (D o b r o w o l s k a, 2010; Lazcano and Dominguez, 2010) and more frequently and the need for environmental protection has drawn attention to the possibility of using municipal and industrial waste in agriculture and horticulture (D obrowols ka et. al. 2007; V abrit et. al. 2007; Zawadzińska and Janicka, 2007). Nature-related management of sewage sludge is the simplest and cheapest way of disposing of this waste material. It makes it possible to re-introduce nutrients and organic matter to the natural cycle (S i u t a and $\mathrm{W}$ a s i a k, 2001).

The specificity of horticultural production makes it possible to use substrates based on compost from municipal and industrial waste, particularly in the cultivation of ornamental plants. It is possible to obtain a substrate appropriate for plant cultivation from municipal sewage sludges after they are composted ( $\mathrm{K} \mathrm{r} \mathrm{z} \mathrm{y} \mathrm{-}$ w y et. al. $2000 \mathrm{a}, \mathrm{b}$ ). During this process, as a result of stabilisation and hygienisation, the heavy metal content and the number of pathogenic microorganisms are reduced and the fertilising ingredients they contain are transformed, which results in an increase in the number of nutrients assimilable by plants (K r z yw y et. al. 1999; Z a w a d zińska and J a n icka, 2007). Substrates with optimal chemical properties for individual species can be obtained by mixing composts from municipal sewage sludge with peat at an appropriate ratio or with other nutrient-poor components with an acidic $\mathrm{pH}$ value and low salt concentration ( $\mathrm{C} \mathrm{z} \mathrm{y} \mathrm{z} \mathrm{y} \mathrm{k}$ et. al. 2002; Z aw a d zi ńs ka and K les s a, 2007). The process of composting municipal sewage sludge with the addition of various structure-forming materials considerably lowers the quantity of undesirable substances in the environment, increases the aeration of the mass, makes it easier to obtain the optimal moisture of the composted mass at a level of $50-60 \%$, and it also results in enriching the compost mass with nutrients for plants and in reducing the concentration 
of heavy metals. The aim of this research was to assess the usability of sewage sludge-based substrates in the cultivation of the horned violet from the Patiola F1 group and to compare them with traditional substrates, such as peat and coconut fibre.

\section{MATERIALS AND METHODS}

Experiments using horned violet cultivars (Viola cornuta L.) from the Patiola F1 group: 'Patiola Pure Yellow', 'Patiola Pure Violet', 'Patiola Violet with Yellow Face', 'Patiola Pure Light Blue', 'Patiola Pure Lemon Yellow', and 'Patiola Tangerine' (Syngenta Seeds), were conducted in the years 2005-2007. In the experiments, four substrates were used: I - substrate from deacidified peat (control); II - coconut fibre; III - substrate from peat and compost $1(1: 1 \mathrm{v} / \mathrm{v}) ; \mathrm{IV}-$ substrate from peat and compost $2(1: 1 \mathrm{v} / \mathrm{v})$. Compost 1 was prepared using municipal sewage sludge (35\%), potato pulp (35\%), and straw (30\%). Compost 2 was prepared using municipal sewage sludge $(35 \%)$, potato pulp (35\%), and sawdust (30\%). After 10 months of composting, the composts were used in the present study; the methods of their preparation can be found in the papers by Krzywy et al. (2000 a) and Krzywy and Krzywy (2003). New compost was prepared in each year of the study. Mineral fertilisation was applied on the basis of chemical analysis of samples of the substrates collected before planting out the plants at the following rates: $\mathrm{N}-250 \mathrm{mg} \times \mathrm{dm}^{-3} ; \mathrm{P}_{2} \mathrm{O}_{5}-$ $200 \mathrm{mg} \times \mathrm{dm}^{-3}$; and $\mathrm{K}_{2} \mathrm{O}-300 \mathrm{mg} \times \mathrm{dm}^{-3}$. A pH value of 6.2 was obtained in all substrates using chalk and dolomite. The chemical composition of the composts and their ingredients after a 10-month composting period are shown in Table 1.

The seedlings produced were planted into pre-prepared substrates according to the method. In the period from 11 to 20 April in all years of the study, violets from the pots were placed on $120 \mathrm{~cm}$-wide beds, at distances of $20 \times 15 \mathrm{~cm}$. Regardless of the year of the study, the experiments were terminated between 11 and 20 June.

The morphological features were measured once - twenty four weeks after planting out the seedlings (between 1 and 10 April) when $80 \%$ of the plants had developed at least one flower. The following features were evaluated: total plant height, plant diameter, number of leaves, length and width of the leaf blade, and the leaf chlorophyll content index in SPAD units (using a Minolta Chlorophyll Meter device determining the light absorption by the leaf blade). For leaf measurements (leaf size and greenness index), 5 representatives of typical oval-shaped leaves were selected from the middle part of the plant. The experiments were conducted using a completely randomized design as two-factor experiments. 24 experimental items were created, with 5 replications of each item consisting of 3 plants. In each of the two years, 360 plants were evaluated. The results of the measurements of morphological features and the chlorophyll content index were analysed statistically by two-factor variance analysis using Statistica 10 software. The same design was used as it was assumed that the substrates were the primary factor in all the experiments, while the cultivars were the secondary factor. Tukey's test was used to verify statistical significance between the means at the significance level of $\mathrm{a}=0.05$.

To determine the relationships between the media, the results obtained were subjected to agglomerative cluster analysis and classified into groups in a hierarchical order by means of Ward's method. The statistical analysis was performed using Statistica software.

\section{RESULTS}

The chemical analysis of substrate components showed that the municipal sewage sludge was characterised by a high $\mathrm{N}, \mathrm{P}$ and $\mathrm{Ca}$ content. The high content of these components in the sewage sludge also affected the richness of the finished composts after the 10-month composting period (Table 1). The finished substrates used in the experiments before planting the plants differed in their nutrient content and salinity levels. The substrate consisting of peat and compost 1 had the highest content of $\mathrm{N}-\mathrm{NO}_{3}, \mathrm{P}$ and $\mathrm{K}$. It was also characterised by the highest salinity level. The peat substrate and coconut fibre had the lowest nutrient content. The chemical analysis showed a high level of $\mathrm{K}$ in the coconut fiber only in the second year of cultivation (Tables 2-3).

The substrates used for cultivation influenced the size and the exterior of horned violet plants from the Patiola group (Tables 4-5). It was shown that plants grown on coconut fibre were the shortest and had the smallest leaf rosettes. Plants grown in compost-containing substrates did not differ from plants grown in peat substrates in terms of their height and diameter. Differences in the features under analysis were also found between individual cultivars. Horned violet plants from the 'Patiola Pure Light Blue' cultivar were the largest, regardless of the year of the study. In the remaining cultivars, differences were found in terms of plant height in the individual growing seasons. Horned violet plants from the 'Patiola Tangerine' cultivar were the shortest in the first growing season, while 'Patiola Pure Yellow' plants were the shortest in the following season (Table 4). In terms of diameter, plants from the cultivars 'Patiola Pure Lemon Yellow', 'Patiola Pure Light Blue', and 'Patiola Violet with Yellow Face' reached the largest size.

The influence of the substrates on the number and size of leaves was shown (Figs 1 and 3). Regardless of the cultivar, pansy plants growing in the peat 
substrate had the largest number of leaves in both seasons. Their leaves were also the largest (the length and width of the leaf blades). A lower number of leaves were recorded for horned violet plants grown in the substrates consisting of peat and compost at a 1:1 ratio. Plants growing in coconut fibre produced the lowest number of leaves. They also had small and narrow leaf blades. It was observed that the plants had more profuse foliage in the second growing season than in the first one.

The differences in the number of leaves in horned violet plants also resulted from the characteristics of individual cultivars. Regardless of the substrate used for cultivation, the cultivars 'Patiola Pure Lemon Yellow', 'Patiola Pure Violet', and 'Patiola Tangerine' had the lowest number of leaves. The other cultivars were characterised by more lush foliage. The cultivars also differed in the size of leaf blades - 'Patiola Pure Yellow' and 'Patiola Tangerine' plants were characterised by the longest leaf blades. The cultivars 'Patiola Pure Yellow', Patiola Pure Yellow Lemon', and 'Patiola Violet with Yellow Face', on the other hand, had the shortest leaf blades. The narrowest leaves were formed by the cultivars 'Patiola Pure Yellow', 'Patiola
Violet with Yellow Face', and 'Patiola Pure Lemon Yellow', while 'Patiola Pure Violet' and 'Patiola Tangerine' plants were characterised by the broadest leaves (Fig. 2). Regardless of the year of the study, horned violet plants cultivated in the peat substrate were characterised by the highest leaf chlorophyll content index. In the first year of cultivation, plants grown in the substrate with compost 1 and in coconut fibre had a less intense colour. Among the cultivars under analysis, 'Patiola Tangerine' plants were distinguished by a higher chlorophyll content index, but only in the second season (Table 6).

The dendrogram in Fig. 4 shows the similarity between the substrates under evaluation in terms of their influence on the morphological features of horned violet plants from the Patiola group. The obtained dendrogram, which illustrates the hierarchy of clusters of individual substrates, was analysed. Based on the Euclidean distance using Ward's method, it was found that cluster 1 was formed by two compost-based substrates and the peat substrate. The coconut fibre substrate was characterised by a long distance from this group, which is also confirmed in Tables 4-6 and Figures 1-3.

Table 1

Chemical composition of composts and components of composts after 10 months of fermentation (years 2004-2005)

\begin{tabular}{|c|c|c|c|c|c|c|c|}
\hline \multirow{2}{*}{$\begin{array}{l}\text { Components of composts } \\
\text { and composts }\end{array}$} & $\mathrm{pH}\left(\mathrm{H}_{2} \mathrm{O}\right)$ & $\mathrm{N}$ & $\mathrm{P}$ & $\mathrm{K}$ & $\mathrm{Ca}$ & $\mathrm{Mg}$ & $\mathrm{Cl}$ \\
\hline & \multicolumn{7}{|c|}{ (g×kg ${ }^{-1}$ D.M.) } \\
\hline Municipal sewage sludge & 7.75 & 38.8 & 28.7 & 5.70 & 20.1 & 2.28 & - \\
\hline Potato pulp & 4.70 & 7.20 & 4.90 & 9.70 & 7.58 & 1.01 & - \\
\hline Rye straw & - & 3.50 & 5.90 & 5.45 & 0.96 & 0.26 & - \\
\hline Sawdust & - & 1.30 & 5.15 & 1.80 & 0.70 & 0.15 & - \\
\hline Compost $1 *$ & 7.02 & 24.0 & 13.8 & 6.09 & 13.0 & 1.40 & 4.34 \\
\hline Compost $2 *$ & 6.83 & 22.0 & 13.0 & 5.25 & 12.8 & 1.22 & 3.65 \\
\hline
\end{tabular}

* Composition of composts converted into dry matter

Compost 1 - municipal sewage sludge (35\%), potato pulp (35\%), rye straw $(30 \%)$

Compost 2 - municipal sewage sludge (35\%), potato pulp (35\%), sawdust from coniferous trees (30\%)

Table 2

Chemical composition of media used before the start of the experiments - autumn 2005

\begin{tabular}{|c|c|c|c|c|c|c|c|c|}
\hline \multirow{2}{*}{ Media } & \multirow{2}{*}{$\begin{array}{c}\mathrm{pH} \\
\left(\mathrm{H}_{2} \mathrm{O}\right)\end{array}$} & \multicolumn{6}{|c|}{ Available forms $\left(\mathrm{mg} \times \mathrm{dm}^{-3}\right)$} & \multirow{2}{*}{$\begin{array}{c}\mathrm{NaCl} \\
\left(\mathrm{g} \times \mathrm{dm}^{-3}\right)\end{array}$} \\
\hline & & $\mathrm{N}-\mathrm{NO}_{3}$ & $\mathrm{P}$ & $\mathrm{K}$ & $\mathrm{Ca}$ & $\mathrm{Mg}$ & $\mathrm{Cl}$ & \\
\hline $\mathrm{I}^{*}$ & 6.20 & 18 & 67 & 17 & 2012 & 230 & 50 & 1.28 \\
\hline II & 5.60 & 12 & 77 & 378 & 94 & 74 & 769 & 2.27 \\
\hline III & 6.10 & 250 & 624 & 965 & 3229 & 351 & 113 & 2.33 \\
\hline IV & 6.50 & 157 & 378 & 705 & 3042 & 281 & 71 & 3.33 \\
\hline
\end{tabular}

* Media components:

I - sphagnum peat; II - coconut fibre; III - compost 1 + sphagnum peat $(1: 1 \mathrm{v} / \mathrm{v}) ; \mathrm{IV}-$ compost $2+$ sphagnum peat $(1: 1 \mathrm{v} / \mathrm{v})$, 
Table 3

Chemical composition of media used before the start of the experiments - autumn 2006

\begin{tabular}{|c|c|c|c|c|c|c|c|c|}
\hline \multirow{2}{*}{ Media } & \multirow{2}{*}{$\begin{array}{c}\mathrm{pH} \\
\left(\mathrm{H}_{2} \mathrm{O}\right)\end{array}$} & \multicolumn{6}{|c|}{ Available forms $\left(\mathrm{mg} \times \mathrm{dm}^{-3}\right)$} & \multirow{2}{*}{$\begin{array}{c}\mathrm{NaCl} \\
\left(\mathrm{g} \times \mathrm{dm}^{-3}\right)\end{array}$} \\
\hline & & $\mathrm{N}-\mathrm{NO}_{3}$ & $\mathrm{P}$ & $\mathrm{K}$ & $\mathrm{Ca}$ & $\mathrm{Mg}$ & $\mathrm{Cl}$ & \\
\hline $\mathrm{I}^{*}$ & 6.30 & 17 & 19 & 24 & 2588 & 275 & 35 & 0.43 \\
\hline II & 5.60 & 8 & 45 & 745 & 58 & 85 & 824 & 1.85 \\
\hline III & 6.40 & 533 & 550 & 853 & 2275 & 337 & 122 & 3.96 \\
\hline IV & 6.60 & 67 & 316 & 263 & 1727 & 292 & 68 & 2.26 \\
\hline
\end{tabular}

* For explanations see Table 2

Table 4

Effect of media on plant height of horned violet from the Patiola group [cm]

\begin{tabular}{|c|c|c|c|c|c|c|c|}
\hline \multirow[b]{2}{*}{ Media (A) } & \multicolumn{6}{|c|}{ Cultivars from Patiola Group (B) } & \multirow[b]{2}{*}{ Mean } \\
\hline & 'Pure Yellow' & 'Pure Violet' & $\begin{array}{l}\text { 'Violet with } \\
\text { Yellow Face' }\end{array}$ & $\begin{array}{l}\text { 'Pure Light } \\
\text { Blue' }\end{array}$ & $\begin{array}{c}\text { 'Pure Lemon } \\
\text { Yellow' }\end{array}$ & 'Tangerine' & \\
\hline \multicolumn{8}{|c|}{$2005 / 2006$} \\
\hline$I^{*}$ & 7.97 & 9.21 & 9.71 & 12.62 & 8.52 & 8.45 & 9.41 \\
\hline II & 7.70 & 7.13 & 7.42 & 11.71 & 6.53 & 5.92 & 8.07 \\
\hline III & 7.38 & 7.53 & 9.75 & 11.92 & 11.01 & 6.66 & 9.04 \\
\hline IV & 8.02 & 9.20 & 8.47 & 11.40 & 11.31 & 7.55 & 9.32 \\
\hline Mean & 7.77 & 8.27 & 9.34 & 11.91 & 9.34 & 6.15 & \\
\hline $\operatorname{LDS}_{0.05}$ & \multicolumn{7}{|c|}{$\mathrm{A}=1.311 \mathrm{~B}=1.786 \mathrm{~A} \times \mathrm{B}=\mathrm{n} . \mathrm{s}$} \\
\hline \multicolumn{8}{|c|}{$2006 / 2007$} \\
\hline I & 9.02 & 11.87 & 12.43 & 13.76 & 11.96 & 11.01 & 11.68 \\
\hline II & 7.74 & 9.11 & 9.27 & 8.69 & 8.30 & 9.41 & 8.75 \\
\hline III & 8.44 & 10.85 & 11.88 & 13.88 & 9.98 & 11.59 & 11.10 \\
\hline IV & 8.15 & 12.11 & 9.87 & 13.14 & 10.70 & 9.84 & 10.64 \\
\hline Mean & 8.34 & 10.99 & 10.86 & 12.37 & 10.24 & 10.46 & \\
\hline $\mathrm{LDS}_{0.05}$ & \multicolumn{7}{|c|}{$\mathrm{A}=1.440 \mathrm{~B}=1.962 \mathrm{~A} \times \mathrm{B}=\mathrm{n} . \mathrm{s}}$. \\
\hline \multicolumn{8}{|c|}{ Mean of years } \\
\hline $\mathrm{I}^{*}$ & 8.50 & 10.53 & 11.07 & 13.19 & 10.24 & 9.73 & 10.55 \\
\hline II & 7.72 & 8.12 & 8.35 & 10.20 & 7.42 & 7.67 & 8.41 \\
\hline III & 7.91 & 9.19 & 10.82 & 12.90 & 10.50 & 9.13 & 10.07 \\
\hline IV & 8.09 & 10.66 & 9.17 & 12.07 & 11.00 & 8.70 & 9.98 \\
\hline Mean & 8.06 & 9.63 & 9.85 & 12.27 & 9.79 & 8.81 & \\
\hline $\mathrm{LDS}_{0.05}$ & \multicolumn{7}{|c|}{$\mathrm{A}=1.377 \mathrm{~B}=1.854 \mathrm{~A} \times \mathrm{B}=\mathrm{n} . \mathrm{s}}$. \\
\hline
\end{tabular}

* For explanations see Table 2 


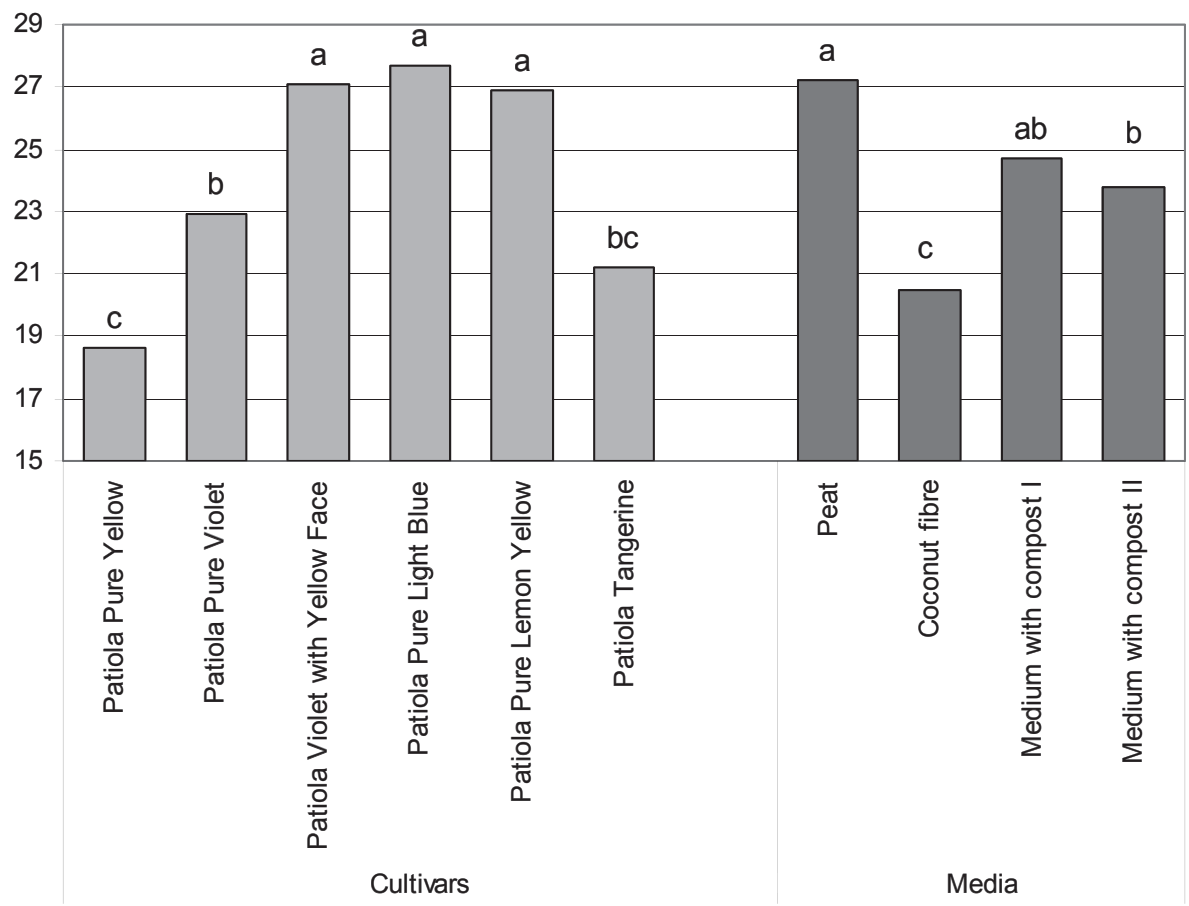

Fig. 1. Effect of cultivars and media on number of leaves of horned violet from the Patiola group - mean of years.

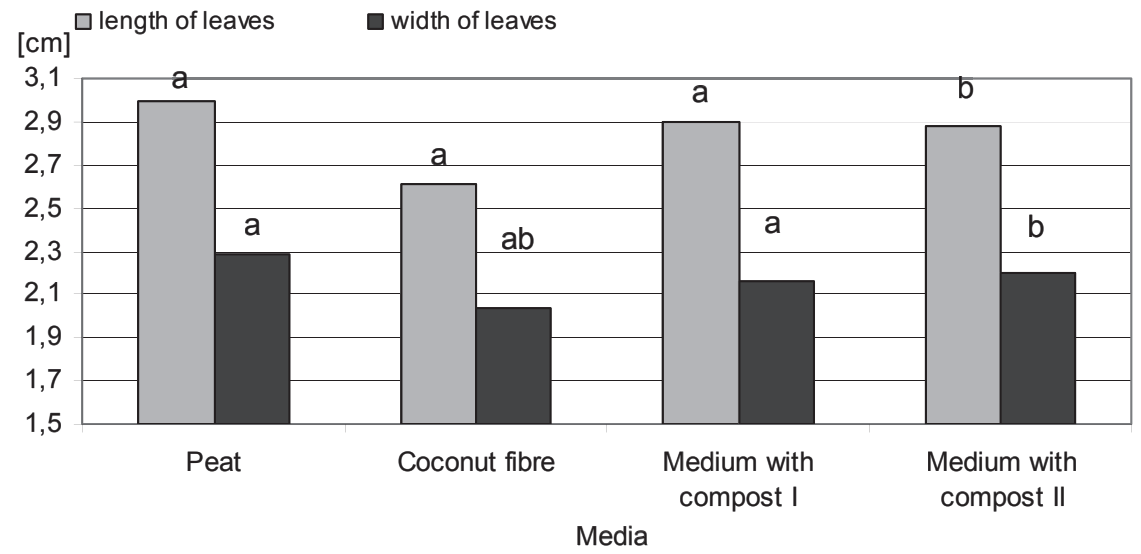

Fig. 2. Effect of media on length and width of leaves of horned violet from the Patiola group [cm] - mean of years.

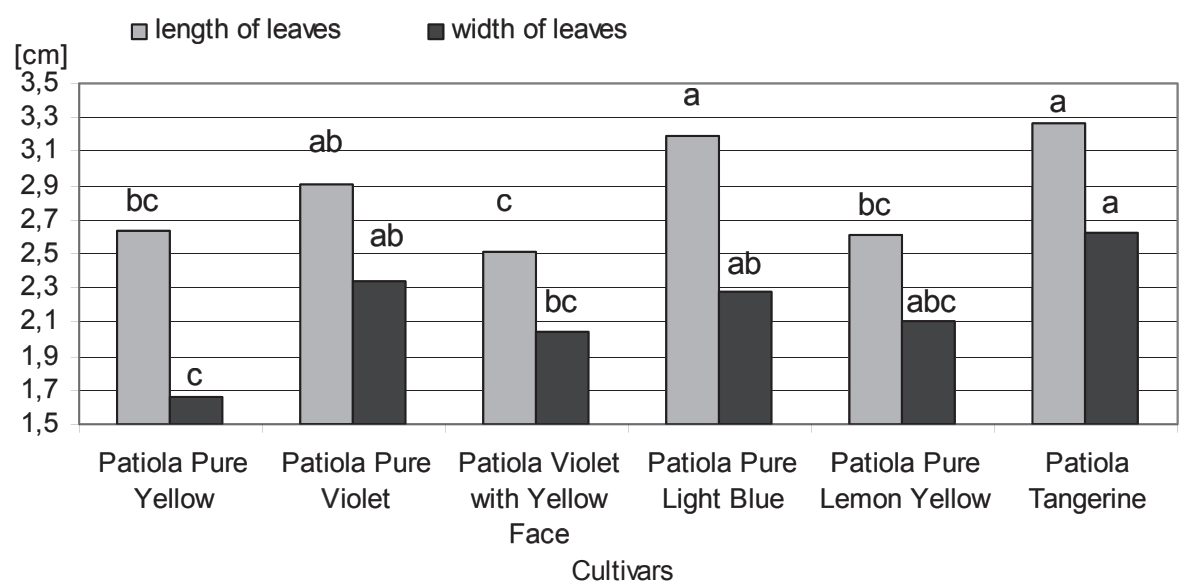

Fig. 3. Length and width of leaves of six horned violet cultivars from Patiola group [cm] - mean o years. 
Table 5

Effect of media on plant diameter of horned violet from the Patiola group [cm]

\begin{tabular}{|c|c|c|c|c|c|c|c|}
\hline \multirow[b]{2}{*}{ Media (A) } & \multicolumn{6}{|c|}{ Cultivars from Patiola Group (B) } & \multirow{2}{*}{ Mean } \\
\hline & 'Pure Yellow' & 'Pure Violet' & $\begin{array}{l}\text { 'Violet with } \\
\text { Yellow Face' }\end{array}$ & $\begin{array}{l}\text { 'Pure Light } \\
\text { Blue' }\end{array}$ & $\begin{array}{l}\text { 'Pure Lemon } \\
\text { Yellow' }\end{array}$ & 'Tangerine' & \\
\hline \multicolumn{8}{|c|}{$2005 / 2006$} \\
\hline $\mathrm{I}^{*}$ & 10.98 & 12.49 & 12.59 & 14.90 & 12.66 & 12.38 & 12.67 \\
\hline II & 9.45 & 9.78 & 11.88 & 11.11 & 11.39 & 11.38 & 10.83 \\
\hline III & 8.48 & 10.23 & 12.76 & 13.34 & 14.84 & 10.24 & 11.65 \\
\hline IV & 11.04 & 11.38 & 11.68 & 13.34 & 14.70 & 10.19 & 12.06 \\
\hline Mean & 9.99 & 10.97 & 12.23 & 13.17 & 13.40 & 11.05 & \\
\hline $\operatorname{LDS}_{0.05}$ & \multicolumn{7}{|c|}{$\mathrm{A}=1.207 \mathrm{~B}=1.644 \mathrm{~A}(\mathrm{~B})=2.956$} \\
\hline \multicolumn{8}{|c|}{$2006 / 2007$} \\
\hline I & 12.01 & 15.84 & 13.64 & 13.20 & 14.60 & 16.02 & 14.22 \\
\hline II & 11.41 & 12.21 & 11.73 & 10.93 & 12.02 & 13.06 & 11.89 \\
\hline III & 11.80 & 13.54 & 15.24 & 14.58 & 14.94 & 14.42 & 14.09 \\
\hline IV & 11.97 & 12.20 & 13.92 & 13.72 & 13.36 & 12.18 & 12.89 \\
\hline Mean & 11.80 & 13.45 & 13.63 & 13.11 & 13.73 & 13.92 & \\
\hline $\mathrm{LDS}_{0.05}$ & \multicolumn{7}{|c|}{$\mathrm{A}=1.384 \mathrm{~B}=1.885 \mathrm{~A} \times \mathrm{B}=$ n.s. } \\
\hline \multicolumn{8}{|c|}{ Mean of years } \\
\hline $\mathrm{I}^{*}$ & 11.50 & 14.17 & 13.12 & 14.05 & 13.63 & 14.20 & 13.45 \\
\hline II & 10.43 & 10.99 & 11.81 & 11.02 & 11.71 & 12.22 & 11.36 \\
\hline III & 10.14 & 11.89 & 14.00 & 13.96 & 14.89 & 12.33 & 12.87 \\
\hline IV & 11.51 & 11.79 & 12.80 & 13.53 & 14.03 & 11.19 & 12.48 \\
\hline Mean & 10.90 & 12.21 & 12.93 & 13.14 & 13.57 & 12.49 & \\
\hline $\mathrm{LDS}_{0.05}$ & \multicolumn{7}{|c|}{$\mathrm{A}=1.323 \mathrm{~B}=1.786 \mathrm{~A}(\mathrm{~B})=2.657$} \\
\hline
\end{tabular}

* For explanations see Table 2

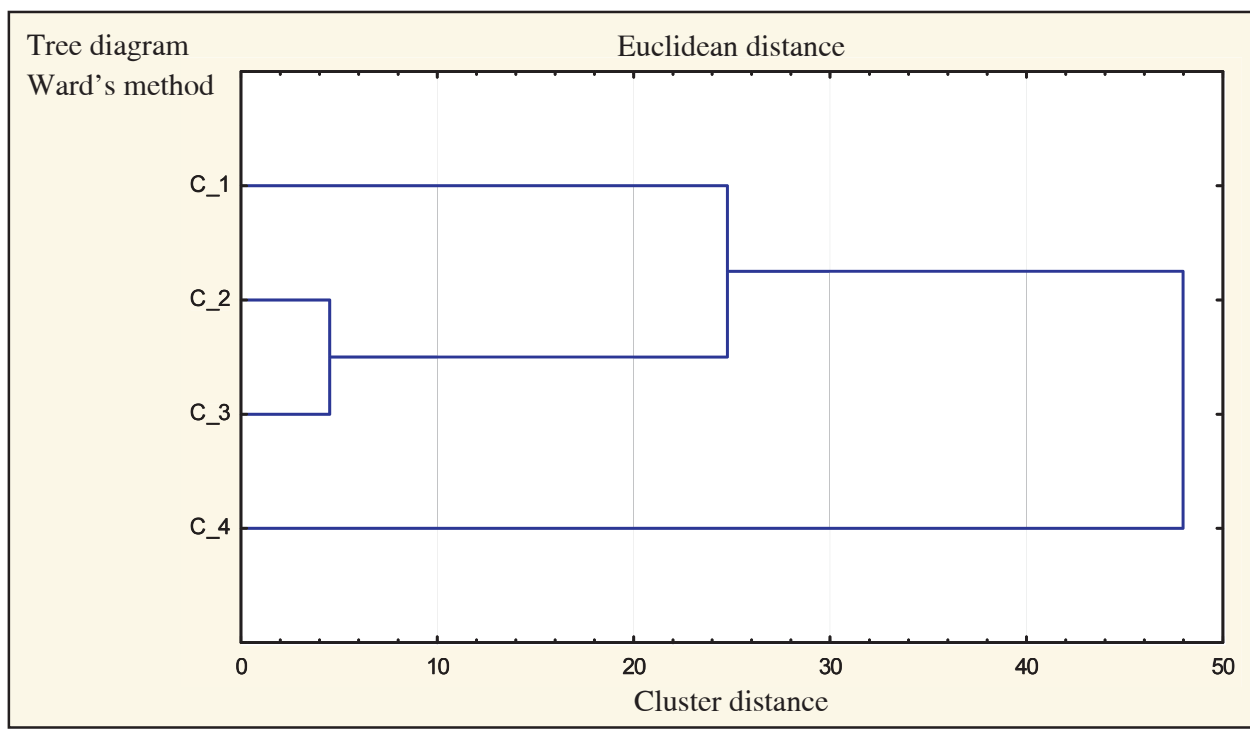

Fig. 4. The dendrogram illustrates the hierarchy of clusters of individual substrates based on the Euclidean distance using Ward's method. 
Table 6

Effect of media on the leaf greenness index of horned violet from the Patiola group [SPAD]

\begin{tabular}{|c|c|c|c|c|c|c|c|}
\hline \multirow{2}{*}{ Media (A) } & \multicolumn{6}{|c|}{ Cultivars from Patiola Group (B) } & \multirow{2}{*}{ Mean } \\
\hline & 'Pure Yellow' & 'Pure Violet' & $\begin{array}{l}\text { 'Violet with } \\
\text { Yellow Face' }\end{array}$ & $\begin{array}{l}\text { 'Pure Light } \\
\text { Blue' }\end{array}$ & $\begin{array}{c}\text { 'Pure Lemon } \\
\text { Yellow' }\end{array}$ & 'Tangerine' & \\
\hline \multicolumn{8}{|c|}{$2005 / 2006$} \\
\hline$I^{*}$ & 47.84 & 48.40 & 46.80 & 48.44 & 47.30 & 48.32 & 47.85 \\
\hline II & 44.02 & 47.40 & 39.56 & 45.10 & 46.52 & 42.68 & 44.21 \\
\hline III & 47.26 & 44.88 & 43.28 & 43.26 & 46.80 & 46.40 & 45.31 \\
\hline IV & 46.58 & 46.52 & 48.02 & 46.24 & 45.54 & 48.20 & 46.85 \\
\hline Mean & 46.43 & 46.80 & 44.42 & 45.76 & 46.54 & 46.40 & \\
\hline $\operatorname{LDS}_{0.05}$ & \multicolumn{7}{|c|}{$\mathrm{A}=2.158 \mathrm{~B}=$ n.s. $\mathrm{A} \times \mathrm{B}=$ n.s. } \\
\hline \multicolumn{8}{|c|}{$2006 / 2007$} \\
\hline I & 56.20 & 57.62 & 58.62 & 52.14 & 56.96 & 61.84 & 57.23 \\
\hline II & 55.38 & 51.94 & 52.56 & 53.02 & 54.54 & 58.94 & 54.40 \\
\hline III & 51.16 & 50.32 & 48.56 & 50.82 & 52.56 & 52.40 & 50.97 \\
\hline IV & 52.30 & 52.54 & 51.50 & 51.94 & 51.60 & 57.78 & 52.94 \\
\hline Mean & 53.76 & 53.11 & 52.81 & 51.98 & 53.92 & 57.74 & \\
\hline $\operatorname{LDS}_{0.05}$ & \multicolumn{7}{|c|}{$\mathrm{A}=1.945 \mathrm{~B}=2.650 \mathrm{~A} \times \mathrm{B}=\mathrm{n} . \mathrm{s}$} \\
\hline \multicolumn{8}{|c|}{ Mean of years } \\
\hline $\mathrm{I}^{*}$ & 52.02 & 53.01 & 52.71 & 50.29 & 52.13 & 55.08 & 52.54 \\
\hline II & 47.70 & 49.67 & 46.06 & 49.06 & 50.53 & 50.81 & 48.97 \\
\hline III & 49.21 & 47.60 & 45.92 & 47.04 & 49.68 & 49.40 & 48.14 \\
\hline IV & 49.44 & 49.53 & 49.76 & 49.09 & 48.57 & 52.99 & 49.90 \\
\hline Mean & 49.59 & 49.95 & 48.75 & 48.87 & 50.23 & 52.07 & \\
\hline $\mathrm{LDS}_{0.05}$ & \multicolumn{7}{|c|}{$\mathrm{A}=2.006 \mathrm{~B}=2.541 \mathrm{~A} \times \mathrm{B}=$ n.s. } \\
\hline
\end{tabular}

* For explanations see Table 2

\section{DISCUSSION}

Sewage sludge-based compost is a rich source of organic substances as well as $\mathrm{N}, \mathrm{P}, \mathrm{Mg}$, and $\mathrm{Ca}$. It contains less $\mathrm{K}$, but it is characterised by a high concentration of salt and an increased content of heavy metals (Ciećko and $\mathrm{Harnisz}, 2002$; Kiepas - K o k o t and Z a b ł o c ki, 2002). To reduce the content of harmful substances, the composts in question were mixed with nutrient-poor peat. The use of sewage sludge for growing ornamental plants is possible after it has been composted and mixed with peat at an appropriate ratio. Numerous authors confirm that such a substrate is appropriate for growing numerous species of ornamental plants, also including bedding plants (A ndre et. al. 2002; Dobrowolska et. al. 2007; Vabrit et. al. 2007). The authors' own research has shown that horned violet plants from the Patiola
F1 group grow and develop well in substrates consisting of a mixture of peat and sewage sludge-based compost at a 1:1 volumetric ratio.

The influence of the substrates on the growth, exterior and foliage of plants depends on the type of substrate, its $\mathrm{pH}$ value, salinity, and nutrient content. The use of substrates with the addition of sewage sludge-based compost has a beneficial effect on plant development. However, this influence depends on the type of compost and the percentage of this compost in the substrate ( $\mathrm{Zawadzińska}$ and Janicka, 2007). The composting time of sewage sludge is also of considerable importance. Long-term composting of sewage sludge results in progressing mineralisation of the composting mass and a reduction in the content of nearly all mineral ingredients (C z y ż y k et. al. 2002).

Coconut fibre is a substrate suitable for the cultivation of numerous ornamental plants, including 
the pansy. Some studies confirm its effective influence on rapid growth and proper development of plants (S t a r t e k et. al 2006; J a n i cka and Dobrow o lska, 2007; Czajka and Szczepaniak, 2006). However, it happens that not all plants respond to the coconut fibre substrate in a positive way. Poorer growth of plants grown in coconut fibre is often connected with high concentrations of salt in the substrate, which results in reduced leaf size, reduced plant height, and inhibition of root growth (C a b r e r a 2003; J a le el et. al. 2008). In the authors' own research, the growth of horned violet plants grown in coconut fibre was poorer, since they had a low number of leaves and the leaves were small. A more rapid exhaustion of nutrients in the substrate may be the reason for poorer growth of plants grown in coconut fibre.

\section{CONCLUSIONS}

1. Composts made from municipal sewage sludge are rich in nutrients. Plants that are grown in substrates with the addition of composts and in peat substrate grow and develop properly without the necessity of introducing top dressing.

2. The addition of municipal sewage sludge composts did not cause observable adverse changes in plants grown.

3. Coconut fiber can be an alternative to peat in the production of horned violet from the Patiola group, despite a slight reduction of plant growth and small leaves.

\section{Acknowledgements}

Research supported by the Ministry of Science and Higher Education of Poland as the part of statutory activities of Department of Horticulture, University of Technology in Szczecin.

\section{REFERENCESS}

Andre F., Guerrero C., Beltaro J., Brito. J. 2002. Comparative study of Pelargonium sp. grown in sewage sludge and peat mixtures. Acta Hort. 573: 63-69.

Cabrera R.I. 2003. Growth, quality and nutrient responses of Azalea hybrids to salinity. Acta Hort. 609: 241-245.

Ciećko Z., Harnis z M. 2002. Wpływ kompostów z osadów ściekowych na zawartość potasu, wapnia i magnezu w wybranych roślinach uprawnych. / Influence of sewage sludge compost for the content of potassium, calcium and magnesium in selected crops. Zesz. Probl. Post. Nauk Rol. 484: 77-86. (in Polish)

Czajka E., Szczepaniak S. 2006. Wzrost kocanek włochatych uprawianych w doniczkach w zależności od rodzaju podłoża. / Growth of licorice plants cultivated in pots, depending on the substrate. Zesz. Probl. Post. Nauk Rol. 510: 97-104. (in Polish)

Czyżyk F., Kozdraś M., Sieradzki T. 2002. Wartość nawozowa kompostów $\mathrm{z}$ osadów ściekowych i słomy. / Fertilizer value of sewage sludge compost and straw. Zesz. Probl. Post. Nauk Rol. 484, 117-124: (in Polish)

Dobrowolska A. 2010. Influence of the medium with addition of cocoa husk on the production of seedlings of selected species and cultivar of bedding plants. Ecol. Chem. Eng. A 17 (9): 1089-1094.

Dobrowolska A., Klessa M., Placek M. 2007. Ocena przydatności podłoży $\mathrm{z}$ dodatkiem kompostu z komunalnego osadu ściekowego w uprawie dwóch gatunków z rodzaju Impatiens. Cz. I. Cechy wegetatywne. / Evaluation of the usefulness of substrates with compost from municipal sewage sludge in the cultivation of two species of the genus Impatiens. Part I. The vegetative features. Folia Univ. Agricul. Stetinensis, Agric. Aliment. Pisc. Zootech. 259 (4): 35-40. (in Polish)

Jaleel C.A., Sankar B., Sridharan R. Panneerselvam R. 2008. Soil salinity alters growth, chlorophyll content and secondary metabolite accumulation in Catharanthus roseus. Turk. J. Biol. 32, 79-93.

Janicka D., Dobrowolska A. 2007. Ocena przydatności torfu i włókna kokosowego w produkcji rozsady bratka ogrodowego z grup Delta i Samba. / Evaluation of use of peat and coconut fibre in production of seedling of Delta and Samba pansy. Folia Univ. Agric. Stetin. Aliment. Pisc. Zootech. 257 (3): 75-80. (in Polish)

Kiepas-Kokot A., Zabłocki Z. 2002. Zmienność zawartości makroelementów i metali ciężkich w osadach ściekowych z oczyszczalni w fabryce kabli „Załom” w Szczecinie. / Variability of macroelement and heavy metal contents in sewage sludge from sewage treatment plant in „Zalom” cable factory in Szczecin. Zesz. Probl. Post. Nauk Rol. 484: 249-254. (in Polish)

Krzywy E., Wołoszyk Cz., Iżewska A. 1999. Zmiany chemiczne zachodzące w kompostach z osadów ściekowych podczas ich fermentacji. Cz. II. Zmiany zawartości form przyswajalnych fosforu i potasu oraz rozpuszczalnych w $0,5 \mathrm{~mol} \times \mathrm{dm}^{-3} \mathrm{HC}$ magnezu i wapnia. / The chemical changes in composts of sewage sludge during fermentation. Part II. Changes in the content of available forms of phosphorus, potassium and soluble in $0.5 \mathrm{~mol} \times \mathrm{dm}^{-3} \mathrm{HC}$ magnesium and calcium. Fol. Univ. Agric. Stetin 1999 Agricultura, 7: 189-193. (in Polish).

Krzywy E., Wołoszyk Cz., Iżewska A. 2000 a. Wartość nawozowa komunalnych osadów ściekowych. / The fertilizer value of municipal sewage sludge. Wyd. AR w Szczecinie: 5-15. (in Polish)

Krzywy E., Wołoszyk Cz., Iżewska A. 2000 b. Ocena przydatności do nawożenia kompostów z osadów ściekowych z oczyszczalni komunalnych. Cz. I. Plonowanie rekultywacyjnej mieszanki traw w uprawie polowej. / Assessment of suitability of municipal sewage 
sludge-based composts for fertilization. Part I. Yield of a mixture of reclamation grasses in field cultivation. Fol. Univ. Agric. Stetin. 211, Agricultura, 84: 199-204. (in Polish)

Krzyw y E., Krzyw y J. 2003. Skład chemiczny odpadów ziemniaczanych i osadów ściekowych w aspekcie możliwości wykorzystania ich do celów nawozowych. / The chemical composition of potato waste and sewage sludge in terms of the possibility of using them for fertilizer. Zesz. Probl. Post. Nauk. Rol. 294: 233-239. (in Polish).

Lazcano C., Dominguez J. 2010. Effect of vermicomost as a potting amendment of two commercially-grown ornamental plant species. Span. J. Agric. Res. 8 (4): 1260-1270.

Siuta J., Wasiak G. 2001. Zasady wykorzystania osadów ściekowych na cele nieprzemysłowe (przyrodnicze). [In: Przyrodnicze użytkowanie osadów ściekowych]. Materiały z IV Konferencji. Bydgoszcz. 4-6 czerwiec, 13-42. (in Polish)

Startek L., Janicka D., Salachna P. 2004 a. Wpływ podłoży i nawożenia na cechy morfologiczne i walory dekoracyjne odmian bratka ogrodowego (Viola $\mathrm{x}$ wittrockiana Gams.) z grupy Collosus. Część I. Wzrost, pokrój i indeks zazielenienia roślin. / Impact of media and fertilization on morphological traits and decorative value of garden pansy varieties (Viola $\mathrm{x}$ wittrockiana Gams.) from Colossus Group. Part I. Growth, habit and greening index. Folia Univ. Agric. Stetin. Agricultura, 234 (93): 371-376. (in Polish)

Startek L., Janicka D., Salachna P. 2004 b. Wpływ podłoży i nawożenia na cechy morfologiczne i walory dekoracyjne odmian bratka ogrodowego (Viola x wittrockiana Gams.) z grupy Collosus. Część II. Liście i kwiaty. / Impact of media and fertilization on morphological traits and decorative value of garden pansy varieties (Viola x wittrockiana Gams.) from Colossus Group. Part II. Leaves and flowers. Folia Univ. Agric. Stetin. Agricultura, 234 (93): 377-382. (in Polish)

Startek L., Janicka D., Dobrowolska A., Pla ce k M. 2006. Wpływ rodzaju podłoża na dynamikę wschodów i czas trwania fazy wegetatywnej bratka ogrodowego z grup Carrera i Butterfly. / Influence of substrate on the dynamics of germination and the duration of the vegetative stage of garden pansy Carrera groups and Butterfly. Zesz. Probl. Post. Nauk Roln. 510: 601-608. (in Polish)

Vabrit S., Uurman K., Põldma P., Jõepera K. 2007. Ornamental quality of Bidens feruifolia 'Golden Star' pot plants depended of composted sewage slud- ge as a component of growing media. Acta Hort. 755, 367-372.

Zawadzińska A., Janicka D. 2007. Effects of compost media on growth and flowering of parviflorous garden Pansy (Viola $x$ wittrockiana Gams.). Part I. Plant growth and conformation. Acta Agrobot. 60 (2), 161-166.

Zawadzińska A., K less a M.2007. Wpływ kompostów z komunalnego osadu ściekowego i wycierki ziemniaczanej na wzrost i kwitnienie pelargonii rabatowej $(P e$ largonium x Hortorum Bailey). / Influence of composts from municipal sewage sludge and potato pulp on growth and flowering of pelargonium (Pelargonium $\mathrm{x}$ Hortorum Bailey). Zesz. Probl. Post. Nauk Roln. 518: 209-217. (in Polish)

\section{Wpływ podłoży organicznych na wzrost i rozwój fiołka rogatego (Viola cornuta $\mathbf{L}$.) z grupy Patiola}

\section{Streszczenie}

Specyfika produkcji ogrodniczej stwarza możliwości wykorzystania podłoży na bazie kompostów z odpadów komunalnych i przemysłowych, szczególnie w uprawie roślin ozdobnych. W latach 2005-2007 przeprowadzono doświadczenia z sześcioma odmianami fiołka rogatego z grupy Patiola F1. Zastosowano 4 podłoża: I - podłoże $\mathrm{z}$ odkwaszonego torfu wysokiego, II - włókno kokosowe III - podłoże z torfu i kompostu $1(1: 1 \mathrm{v} / \mathrm{v})$, IV- podłoże z torfu i kompostu $2(1: 1 \mathrm{v} / \mathrm{v})$. Kompost 1 sporządzono z komunalnego osadu ściekowego (35\%), wycierki ziemniaczanej (35\%) i słomy (30\%). Kompost 2 sporządzono z komunalnego osadu ściekowego (35\%), wycierki ziemniaczanej (35\%) i trocin (30\%). Do badań użyto kompostów po 10 miesiącach kompostowania. Dodatek kompostów z komunalnego osadu ściekowego nie powodował niekorzystnych, widocznych zmian na uprawianych roślinach. Komposty sporządzone z komunalnego osadu ściekowego są zasobne w składniki pokarmowe. Rośliny uprawiane $\mathrm{w}$ podłożach $\mathrm{z}$ dodatkiem kompostów oraz w podłożu torfowym rosną i rozwijają się prawidłowo bez konieczności wprowadzania nawożenia pogłównego. 
